\title{
Sastra, Kota, dan Sumatera Barat: Perubahan Masyarakat Perkotaan dalam Karya Sastra
}

\author{
Sudarmoko \\ Leiden University Institute for Area Studies, Leiden, The Netherlands
}

\begin{abstract}
Abstrak
Banyak penulis karya sastra dalam sastra Indonesia modern berasal dari Sumatera Barat. Sebagian karya sastra itu membahas persoalan masyarakat di Sumatera Barat. Artikel ini menelisik sebagian persoalan yang menjadi perhatian dari karya sastra yang dibahas, dalam kaitannya dengan persoalan urban atau perkotaan. Secara umum, tulisan ini bertujuan untuk mendapatkan gambaran bagaimana perubahan sosial budaya yang diakibatkan oleh arus urbanisasi dan modernisme yang terjadi dan dialami oleh masyarakat Sumatera Barat. Secara khusus, karya sastra yang dibahas dalam artikel adalah prosa yang ditulis oleh para pengarang dari Sumatera Barat. Dengan demikian, pandangan para pengarang Sumatera Barat terhadap perubahan dan dinamika masyarakat kota yang ada di provinsi ini menjadi fokus tulisan ini, karena mereka mewakili masalah-masalah yang muncul dari lingkungan paling dekat dari pengarang. Dari pembacaan karya yang dibahas, persoalan pendidikan, kemiskinan, hubungan antar individu, perubahan kebiasaan, gaya hidup modern, hingga kebudayaan dan pengelolaannya menjadi persoalan yang diungkap dalam karya sastra. Resistensi terhadap pengaruh kehidupan kota dalam hubungannya dengan masyarakat pedesaan atau kampung, juga menjadi sebuah persoalan yang selalu tarik menarik dalam kehidupan sehari-hari. Artikel ini juga membuktikan bahwa karya sastra berfungsi sebagai medium yang penting untuk mengkritik pembangunan dan perubahan dari kehidupan masayarakat di perkotaan.
\end{abstract}

Kata kunci: prosa, sastra kota, sastra Indonesia, modernisme, Sumatera Barat

\begin{abstract}
There are many writers in modern Indonesian literature originated from West Sumatra. Some of their works explore society's problem related to West Sumatra. This paper investigates parts of the problems which become the concern of the works, in relation to the urban themes. In general, this paper aims to get a portrait of how the social and cultural changes influenced by the urbanism and modernism within the people of West Sumatra. Specifically, the literary works which are discussed in this paper are proses written by West Sumatran writers. Therefore, the writers' views toward the changes and dynamics of urban society in the province are the focus of this study since they represent the problems raised from the very close environment. Based on the analysis, the problems of education, poverty, individual relations, customary changes, modern life style and culture management become main problems presented in the literary works. The resistance and effect of the urban life, in contrast to the society in rural or villages, also become a problem that always interrelated in daily life. This paper also proofs that literary works function as an important medium to criticize the development and change of the society life in urban setting.
\end{abstract}

Keywords: prose, urban literature, Indonesian literature, modernism, West Sumatra 


\section{Pendahuluan}

Sastra dan kota, atau daerah urban, memiliki hubungan dalam beberapa hal. Selain sebagai salah satu faktor pendukung utama produksi sastra (penerbitan dan percetakan, pendidikan, distribusi dan ekonomi), kota juga merupakan bagian penting yang diolah dalam karya sastra (misalnya dalam latar, penokohan, konflik). Artikel ini membahas gambaran kota dalam karya sastra yang ditulis oleh para pengarang Sumatera Barat. ${ }^{1}$ Karya sastra yang dijadikan bahan analisis dalam artikel ini adalah Kembali ke Pangkal Jalan karya Yusrizal KW, novel Andika Cahaya karya Darman Moenir, novel Lonceng Cinta di Sekolah Guru karya Khairul Jasmi, dan kumpulan cerpen Kaki yang Terhormat karya Gus tf Sakai. Karya-karya yang dibahas memperlihatkan bagaimana Padang menjadi bagian penting dalam pandangan para pengarang Sumatera Barat. Persoalan kampung dan rantau dalam sejumlah cerpen Yusrizal KW, misalnya, menawarkan pilihan yang pelik. Kampung masih menjadi lingkungan yang ideal, baik

1 Artikel ini didasarkan pada penelitian yang dilakukan dengan bantuan dana dari program The Australian Indonesian Research Institute for Humanity and Development, 2012, no 01/BBPT/ SPK/PNP/B.IV/Unand-2012. Penulis mengucapkan terima kasih kepada Donny Eros dan Rebecca Fanany yang telah memberikan masukan dan komentar dalam versi awal penelitian dan penulisan artikel ini. Obervasi lapangan dan wawancara dalam membangun dan mengembangkan ide artikel ini dibantu oleh Ka'bati, Heru Joni Putra, Farid Al Faruqi, dan Esha Tegar Putra. Namun demikian, kekurangan dalam menafsirkan dan menganalisis ada pada penulis. dalam pengertian denotatif maupun konotatif. Kampung merupakan tempat yang nyaman, bersih, menawarkan kehidupan yang relatif kondusif bagi masyarakat. Bagi masyarakat Minangkabau, kampung dan rantau, darek dan pasisie, tidak hanya memiliki makna geografis, tetapi lebih jauh memiliki makna budaya dan konsep nilai yang ada di dalamnya.

Di lain sisi, kota yang menjadi tempat tujuan rantau penuh silang sengketa, kriminal, trik dan intrik, serta sesak oleh berbagai persoalan. Dalam novel Darman Moenir, sebagai contoh lain, kota digambarkan sebagai tujuan rantau, yang pada mulanya sebagai tempat tujuan pendidikan. Memang, pada kebanyakan kasus, alasan pendidikan merupakan sebab perpindahan orang dari desa atau kampung ke kota. Transformasi dari kampung ke rantau ini secara jeli digambarkan oleh Darman Moenir. Meskipun, selain sebagai tempat sementara untuk memperoleh pendidikan, kota ternyata juga menawarkan pilihan lain sebagai tempat tinggal, karir, dan usaha lain. Meskipun, karena para penduduk yang tinggal di kota berasal dari berbagai latar belakang yang berbeda, maka terbentuklah persoalan yang kompleks di perkotaan. 
Persoalan urban atau perkotaan saat ini menjadi penting karena perkembangan budaya mengarah pada persoalan modernisme. Hal ini dipengaruhi dan diakibatkan oleh perkembangan sosial politik ketika pemerintah dan perangkat sistem sosial mengarah pada sistem yang lebih modern. Kota-kota mulai tumbuh, bahkan perangkat perkotaan dan modernisme ini telah menyentuh dan menjadi bagian masyarakat hingga ke pedesaan atau masyarakat rural. Sementara itu sastra bagi sebuah kota adalah bentuklainyang merekamdanmendorongatau menginspirasi kehidupannya. Sayangnya, berbagai nilai yang ada dalam karya sastra, bagi kebanyakan kota di Indonesia, masih sangat sedikit diperhatikan. Bisa jadi, hal ini disebabkan oleh orientasi pembangunan dan kebijakan yang masih melulu mendasarkan diri pada materi dan hal-hal yang konkret. Ditambah lagi, karena alasan profesi dan lingkungan kreatif, banyak pengarang yang memilih untuk tinggal di daerah sekitar kota. Banyak peluang dan kesempatan yang dapat membangun kondisi kreatif seni, seperti diskusi, lembaga atau komunitas seni, peristiwa kesenian, akses informasi dan media, hingga faktor pendukung hidup lainnya terdapat di kota.

Penelitian dan karya ilmiah mengenai hubungan karya sastra dan fenomena masyarakat urban ini meskipun masih sedikit dilakukan, namun sudah menjadi pembahasan yang dilakukan oleh para kritikus dan peneliti. Sebagai contoh, dua buku yang masing-masing berasal dari disertasi, Urban Space in Contemporary Egyptian Literature (Naaman, 2011) dan October Cities the Redevelopment of Urban Literature (Rotella, 1998), menghadirkan penelitian yang mendalam mengenai hubungan antara sastra dan kota. Naaman menelusuri sejarah Kota Kairo berdasarkan informasi yang terdapat dalam karya-karya sastra kontemporer. Karya-karya sastra itu menyimpan ingatan dan disampaikan secara hidup oleh pengarangnya. Naaman juga menemukan fakta-fakta di lapangan dan dokumentasi yang dirujuk dalam karya sastra yang dibahasnya. Sementara itu Rotella memfokuskan penelitiannya pada sejumlah karya sastra yang ditulis oleh para penulis Amerika yang menghasilkan karya antara tahun 1945-1965, yang mengolah persoalanpersoalan kemanusiaan yang terjadi di beberapa kota. Kedua kajian dalam dua buku itu memiliki kemiripan dalam menemukan fakta-fakta yang terdapat dalam karya sastra dan hubungannya dengan kebenaran sejarah dan bukti di lapangan.

Di Indonesia, kajian mengenai kota dan seni ini salah satunya muncul dalam jurnal Kalam (No. 19, 2002). Lauren Bain, dalam artikelnya "Indonesia dari Sebuah Hotel" melihat perkembangan Jakarta dari satu lokasi, Hotel Indonesia. Dari situ ia melihat 
Novel itu sebagian besar ditulis di Hotel Indonesia oleh Christoper Koch. Penelitian terkini mengenai hubungan karya sastra dan kota dilakukan oleh Andy Fuller (2010 dan 2011). Sementara itu Disertasi Andy Fuller membahas tentang sisi keurbanan dalam karya-karya Seno Gumira Ajidarma, Sastra dan Politik: Membaca Karya-karya Seno Gumira Ajidarma melihat bagaimana berbagai kejadian, terutama yang terjadi di kota, dieksplorasi dalam karya sastra. Manneke Budiman (2006) menyajikan fenomena perkotaan dalam karya sastra yang ditulis oleh para pengarang perempuan Indonesia. Ia melihat sisi lain ketika kota dan berbagai persoalannya dibahas oleh para pengarang perempuan. Menurutnya, perempuan, terutama pada era kesusasteraan Indonesia yang lebih bebas selepas era reformasi, mampu mengungkapkan berbagai persoalan perempuan secara lebih luas dan terbuka. Pandangan para penulis perempuan terhadap kota memiliki perspektif dan kesan yang berbeda dibandingkan dengan pengarang laki-laki. Kota dengan berbagai peristiwa di dalamnya, seperti kekerasan, ancaman dan bahaya, disampaikan secara khas oleh para pengarang perempuan. Bisa jadi, bagi pengarang laki-laki hal-hal yang demikian itu tidak secara mendalam dikesan dan dibicarakan secara sensitif.

Ketiga karya sastra yang akan dibahas dalam penelitian ini diterbitkan pada tahun 2012. Sejauh penelusuran kepustakaan yang ada, ditemukan dua tulisan yang membahas masing-masing karya Darman Moenir dan Khairul Jasmi. Tulisan pertama oleh Makmur Hendrik, "Lonceng Cinta Khairul Jasmi” dimuat dalam harian Haluan, 19 April 2012. Tulisan ini berisi resensi atas novel yang ditulis oleh Khairul Jasmi. Dalam pandangan Hendrik, novel ini membahas persoalan guru dan siswa di sebuah sekolah agama di Kota Padangpanjang yang menarik diolah oleh pengarangnya. Kekuatan psikologis tokoh dan peristiwa yang ada dalam novel ini merupakan kekuatannya.

Tulisan lain adalah "Biografi Museum Kekuasaan, Membaca Novel Andika Cahaya Karya Darman Moenir" yang ditulis oleh Fadlillah Malin Sutan dan dimuat di harian Haluan, 8 Juli 2012. Dalam tulisannya, Fadlillah mengurai berbagai kebusukan dan praktik korup di lembaga pemerintah, dalam hal ini museum wilayah yang dikelola secara korup. Fungsi ideal yang diharapkan dari lembaga seperti ini dalam novel Darman Moenir ternyata malah dikalahkan oleh perilaku para pengelolanya. Museum yang menjadi setting novel ini menjadi sebuah gambaran bagaimana praktik-praktik para abdi negara berlaku.

Berbeda dari pembahasan yang sudah dilakukan oleh para penulis dan peneliti lain, artikel ini akan memfokuskan arah analisis pada bagaimana kota dan 
berbagai permasalahannya dibahas oleh para pengarang Sumatera Barat dalam karyakarya terkini. Permasalahan yang akan dibahas dalam tulisan ini adalah bagaimana gambaran dan persepsi pengarang Sumatera Barat tentang lingkungan urban. Secara lebih detil, permasalahan yang akan diteliti adalah bagaimana karya sastra yang dipilih menggambarkan lingkungan urban dan persoalan sosial budaya yang ada, terutama dalam penggunaan latar cerita. Kemudian, bagaimana kota direpresentasikan dalam narasi yang diciptakan oleh para pengarang dari Sumatera Barat. Terakhir, bagaimana perubahan dan dinamika masyarakat dalam memandang persoalan rantau dan rural.

\section{Pembahasan}

\section{Kembali ke Pangkal Jalan: Mengungkap} Sisi Tersembunyi Masyarakat Perkotaan

Cerpen-cerpen Yusrizal KW dalam kumpulan cerpen Kembali ke Pangkal Jalan memperlihatkan bagaimana masyarakat Minangkabau berada dalam dua lokasi, kampung dan rantau. Kampung menjadi tempat yang ideal bagi cerita dan tokohtokoh dalam sebagian cerpen Yusrizal. Persoalan utama bagi masyarakat yang tinggal di kampung adalah rantau, baik sebagai pelaku rantau/perantau atau akibat yang ditimbulkannya.

Sudut pandang terhadap persoalan ini memang tidak lengkap, karena pengarang memilih untuk melihat persoalan dari sudut pandang masyarakat atau tokoh yang tinggal di kampung. Salah satu gambaran yang lebih lengkap terdapat dalam cerpen "Kembali ke Pangkal Jalan" dan "Orang Dalam". Dalam cerpen "Kembali ke Pangkal Jalan" diceritakan seorang anak yang sudah cukup dewasa sehingga ingin merantau untuk mendapatkan kehidupan yang lebih baik, sekaligus juga ingin mengetahui sejarah ayahnya yang tidak kembali dari perantauan. Dalam perantauan inilah berbagai godaan terjadi, seperti kehidupan yang lebih mewah, uang yang banyak, hingga godaan perempuan. Godaan ini yang menjadi topik utama sebagai persoalan psikologis para perantau, yang ternyata dialami oleh ayah tokoh utama dalam cerpen ini, yang memilih untuk tinggal dan hidup dengan berbagai hal yang didapati di rantau dibandingkan untuk pulang dan hidup bersama keluarga di kampung.

Merantau merupakan salah satu pola kehidupan yang dianut oleh kebanyakan masyarakat Minangkabau. Merantau, pertama-tama, adalah perpindahan secara fisik, untuk kepentingan ekonomi, pendidikan, agama, dan lainnya. Pada akhirnya, untuk masa kini yang penuh dengan kemajuan fasilitas dan teknologi, merantau secara fisik tidak lagi diutamakan. Kita dapat mencari penghidupan dengan bantuan kemajuan ini sehingga masalah tempat atau 
lokasi tidak menjadi penghalang. Merantau pemikiran menjadi sebuah kenscayaan untuk menggantikan merantau fisik, yang pada beberapa sisi merugikan kampung halaman.

"Ia melihat foto ayahnya terpajang. Ia mengingat ibunya seketika. Ayah yang lemah niat, langkah, dan iman. Ya, Tuhan, di rantau kekayaanlah ayah ternyata menemukan ujung jalan yang tak memberi pikiran jalan pulang. Dan, ia ingat orang-orang kampungnya yang merantau, tapi tak berkabar berita ke sanak saudara serta anak dan istrinya. Kecuali, hanya kabar angin yang mengabarkan bahwa perantauperantau lupa kampung itu telah menjadi kaya raya. Telah lupa pulang. Telah putus ke pangkal jalan", (KW Yusrizal, 2012: 78).

Pandangan baru untuk memperbaiki pengertian merantau, dari fisik ke pemikiran, dialami oleh Ombing, tokoh utama cerpen ini. Pengalaman secara cukup lama dalam praktik merantau, yang bagi sebagian masyarakat dirasa merugikan, karena kekurangan tenaga potensial dalam membangun kampung halaman. Kdarena itu, pengertian baru dalam memandang pengertian merantau merupakan sebuah ajakan yang patut untuk dimunculkan.

"Dengan kepastian, ia melihat bayangan kakeknya tersenyum karena ia meyakini, bahwa ujung jalan yang benar akan membuatnya arif pada makna rantau pikiran dan kampung halaman. Setelah itu, Ombing pun memulai kembali di pangkal jalan, menuju rantau pikiran!", (KW Yusrizal, 2012: 81).

Cerpen yang secara khusus menggambarkan kehidupan di Padang adalah “Orang Dalam”. Cerpen ini menggambarkan bagaimana seorang tokoh selalu percaya bahwa segala urusan yang berkaitan dengan aktivitas sosial dan publik selalu memerlukan bantuan orang dalam agar urusan itu berhasil. Demikian juga dengan masalah birokrasi, termasuk dalam pengurusan surat-surat hingga seleksi pegawai negeri di lingkungan kantor pemerintahan provinsi yang melibatkan istri sang tokoh. Kepercayaan atas perlunya orang dalam ini menggambarkan buruknya birokrasi yang terjadi. Meskipun fenomena ini terjadi tidak hanya di lingkungan perkotaan, karena intensitas yang terjadi di perkotaan lebih tinggi, gambaran negatif ini jadi melekat dalam kehidupan keseharian di perkotaan.

Gambaran negatif perkotaan ini juga muncul dalam cerpen "Anak Perempuan Ayah". Tokoh Arsim, seorang anak lakilaki yang ingin menjadi anak perempuan, pergi meninggalkan rumahnya karena keinginannya untuk berpakaian dan berprofesi, bahkan untuk berubah menjadi perempuan itu tidak dikabulkan oleh ayahnya. Sementara itu, preman pasar yang 
selalu mengganggu ketenangan bisnis rumah makan ayahnya mulai terjadi, karena Cilun, preman pasar itu, dibebaskan dari penjara. Di lain pihak, orang tua Arsim rindu pada Arsim dan akan merelakan anaknya itu untuk menjadi perempuan jika anak itu kembali. Dan kemudian tanpa diduga, Arsim pulang. Ia telah menjadi persis seperti perempuan. Keluarganya senang menerima kedatangan Arsim. Setelah mengetahui ulah Cilun, yang mengganggu ketenangan masyarakat, pedagang, dan juga ayahnya, Arsim kemudian membunuh Cilun. Fenomena ini terjadi, salah satunya, karena keberadaan para preman yang kebanyakan pengangguran. Di sisi lain, sosok Arsim yang transgender merupakan fenomena menarik lainnya dari dunia metroseksual. Melalui cerpen ini, Yusrizal memperlihatkan bahwa di kota Padang sendiri fenomena ini sudah terjadi.

Padang yang sudah menjadi kota menengah di Indonesia juga menerima akibat lain dari kepadatan penduduk, yaitu berdirinya kompleks-kompleks perumahan. Tanah-tanah yang sebelumnya merupakan sawah, ladang, perkebunan, berubah menjadi kompleks perumahan. Berbagai persoalan di kompleks perumahan ini juga muncul, seperti yang ditunjukkan dalam cerpen Sang Pengeluh. Keluarga Unai, memiliki sifat mengeluh, yang selalu mengadukan segala macam persoalan kepada tokoh Aku. Hampir setiap hari ia datang ke rumah Aku dan mengadukan banyak hal, yang sebenarnya menjadi konsumsi domestik keluarganya saja. Mulai dari soal makanan, keperluan keluarga, peristiwa sehari-hari, hingga soal lain. Inilah yang menjadi fenomena umum masyarakat perkotaan, terutama di Kota Padang, di mana persoalan-persoalan domestik dan sehari-hari selalu dikeluhkan, diceritakan, dan tidak ada lagi privasi atau rahasia keluarga.

Cerpen-cerpen Yusrizal KW secara ironis melihat dan mencatat dialektika dan persoalan yang banyak terjadi di sekitar masyarakat, terutama Minangkabau. Persoalan metantau menjadi perhatian penting sebagai salah satu tradisi yang menciptakan dialektika. Sementara kehidupan seharihari di perkotaan secara tidak langsung dibandingkan dengan kehidupan kampung/ rural yang ideal. Dalam bagian ini, kota menawarkan berbagai perubahan, yang ditekankan oleh Yusrizal dengan berbagai sisi buruk yang ada di dalamnya. Peringatan ini menjadi salah satu pesan penting dalam cerita-cerita yang disajikannya.

\section{Kaki yang Terhormat: Modernisme,} Persoalan Keluarga dan Masyarakat

Cerpen-cerpen yang terangkum dalam kumpulan Kaki yang Terhormat (2012) ini merupakan rekaman seluruh cerpen bergaya realis yang pernah ditulis oleh Gus tf Sakai. Meskipun dikelompokkan dalam genre cerpen 
realis, cerpen-cerpen dalam kumpulan ini sebenarnya memiliki pengertian realis dalam arti sumber cerita yang dapat ditelusuri asalusulnya. Sejumlah cerpen seperti "Kulah", "Upit”, "Kaki yang Terhormat”, "Kak Ros", "Orang Bunian", "Liang Harimau", dan "Lak-uk Kam", sepertinya berasal dari cerita atau legenda yang diketahui secara umum dalam masyarakat (tertentu).

Jika realis yang dimaksud adalah ceritanya benar-benar ada dan kemudian diolah kembali menjadi cerita baru, sepertinya cerpen-cerpen ini tidak masuk dalam kategori itu. Realis dalam kategori cerpen-cerpen ini dapat saja mengukuhkan cerita yang belum tentu nyata, dan begitulah kebanyakan ceritanya, dan kemudian mendapatkan tempat dalam bentuknya yang lain dalam cerita Gus tf Sakai.

Hubungan atau relevansi karya dengan kenyataan, dalam hal ini cerita lain, adalah salah satu kata kunci dalam cerpencerpen Gus tf Sakai. Intertekstualitas mungkin saja terjadi ketika Gus tf Sakai mengolah berbagai sumber menjadi ceritanya. Pembaca barangkali terkesan dengan ketidaksatuan penulisan di halaman judul, "kumpulan cerita" dengan halaman judul di dalam dan di halaman katalog, "kumpulan cerita pendek" dan "kumpulan cerpen". Satu yang pertama dengan kedua frase kedua seolah mengesankan pemaknaan atau maksud yang berbeda dalam buku ini. Bisa jadi ada dua atau lebih pengertian bagi pembaca dan juga bagi Gus tf Sakai ketika mempersiapkan buku ini menjadi satu maksud.

Cerpen "Upit" yang mengawali kumpulan cerpen ini bercerita tentang perilaku khas urban yang bagi masyarakat rural, dan juga bagi entitas masyarakat tertentu terkesan tabu. Kisah tentang seorang lelaki yang sudah berusia dan seharusnya sudah menikah, kemudian berusaha dengan cara menagih balas budi atas hutang seseorang untuk menikahi anaknya. Sebenarnya motif pernikahan yang diinginkannya hanyalah untuk menutupi perilakunya yang menyimpang, bercinta dengan seorang lelaki, homoseksual. Kehidupan keluarga itu terasa asing dan aneh bagi sang istri, yang jarang mendapatkan perlakuan sebagai istri. Sementara di waktuwaktu tertentu, ia malah mendengar dan merasakan suaminya menghabiskan waktu dengan lelaki, entah tamunya atau lebih tepatnya pasangan suaminya, di ruang tamu. Si istri yang kemudian mengenal tetangganya yang tinggal di depan rumah, merasa mendapatkan teman dan menjadi seseorang yang dihargai. Akan tetapi, berkat kekuasaan dan sikap si suami yang memberikan bantuan kepada masyarakat, sang suami mampu mempengaruhi dan menyingkirkan tetangganya yang merupakan seorang pelukis itu. Si istri harus menerima 
kenyataan itu, demi kelangsungan keluarga dan harga dirinya dalam masyarakat.

\section{Cerpen "Kaki yang Terhormat",} yang juga menjadi judul kumpulan cerpen ini berkisah tentang seorang nenek yang hidup di sebuah desa di Kota Payakumbuh. Ia sangat suka berjalan kaki dan mendaki bukit. Anaknya, Harun, sudah besar dan pergi merantau ke kota besar lain di Pulau Jawa. Ia hanya ditemani oleh keluarga yang masih tinggal di rumah gadang dan menghabiskan banyak waktu dengan cucucucunya dan kesenangannya untuk berjalanjalan di sekitar rumahnya. Menurut kabar, di perantauan, Jakarta, Harun sudah menjadi kaya raya. Bahkan, di kampungnya ia terkenal dengan sebutan Helikopter Harun, karena kabarnya ia ke mana-mana pergi dengan helikopter. Ia menjadi legenda bagi orang-orang di kampungnya. Suatu saat, pembangunan di kampung itu akan segera dimulai, yang dibuktikan dengan adanya sejumlah alat-alat berat dan orang-orang yang akan mengerjakan pembangunan sudah datang. Harunlah yang menjadi inisiator dari pembangunan itu. Pembangunan yang akan dilaksanakan adalah pelebaran jalan ke arah bukit. Bukit Kaki itu akan diruntuhkan dan akan dibangun pabrik semen di bawahnya. Namun demikian, pada saat itu juga tersiar kabar bahwa Harun terlibat kasus korupsi. Orang-orang di kampungnya hingga ke kota kecamatan membicarakan berita korupsi itu. Orang-orang percaya bahwa Harun terlibat kasus korupsi karena bertentangan dengan kepercayaan ibunya, si Nenek, yang menaruh kenangan pada Bukit Kaki itu. Namun, ada juga yang percaya bahwa Harun terlibat kasus itu karena ia selalu naik helikopter, tidak pernah menggunakan kakinya untuk berjalan, yang berarti ia tidak melihat keadaan secara langsung dengan mengalaminya.

Kedua cerpen Gus tf Sakai ini berbicara tentang kekhawatiran masuknya arus modernisme dan urbanisme ke dalam masyarakat. Pada cerpen "Upit” digambarkan bagaimana kehidupan warga masyarakat di sebuah kompleks perumahan di sebuah kota sangat individualis. Mereka tidak peduli dengan satu sama lain. Kehidupan yang menjadi rutinitas warga adalah aktivitas ke kantor, sekolah, dan tempat lain sebelum pukul 08.00 pagi. Setelah itu kehidupan menjadi lengang. Perilaku yang menurut ukuran masyarakat menyimpang dialami oleh tokoh Abang, suami Upit. Abang selalu membawa teman lelakinya ketika pulang kerja, dan biasanya sudah malam. Ia kemudian menemani teman lelakinya itu hingga malam atau pagi. Upit dibiarkan tidur sendiri di lantai atas. Warga masyarakat bukannya tidak tahu, seperti yang dirasakan oleh Upit, karena mereka bisa melihat kelakukan Abang. Akan tetapi Abang dianggap oleh warga sebagai orang dermawan, yang selalu memberikan 
bantuan apabila warga melakukan kegiatan atau perayaan bersama. Dengan bantuan inilah warga menutup mulut mereka, tidak memberikan reaksi atas perilaku Abang. Sebaliknya, warga justru mengusir Haris yang tampak menjalin hubungan akrab dengan Upit. Haris adalah tetangga yang tinggal di depan rumah pasangan Abang dan Upit.

Dalam cerpen "Kaki yang Terhormat", industrialisasi dimaknai sebagai sebuah ciri dari kemajuan. Harun yang merupakan warga dari kampung di mana keluarganya tinggal, bahkan merencanakan untuk membangun pabrik, dengan menghancurkan sesuatu yang sangat berharga bagi ibunya sendiri. Industrialisasi, yang menjadi ciri dari modernisme sekaligus perkembangan urban, telah masuk ke berbagai penjuru wilayah. Lalu terjadilah pengalihan fungsi lahan, dari lahan agraria yang sebenarnya menjadi penyangga kehidupan, termasuk mereka yang tinggal di kota, banyak yang dialihfungsikan menjadi lahan industri. Ekspansi industrialisasi ini lamban laun merusak kelanggengan kehidupan, tidak hanya bagi masyarakat rural, tetapi juga masyarakat urban.

"Dan, memang, saat itu akhirnya datang. Banyak sekali orang, para pekerja dengan alat-alat berat entah apa, datang ke kampung kami. Pohon-pohon pun direbahkan, bagianbagian puncak Bukit Kaki diledakkan, tapi belum ada tanda-tanda Mak Etek bakal pulang. Beberapa paman, yang biasa kami panggil mamak, menyabarkan Nenek. Tak ada reaksi dari Nenek, kecuali kian sering duduk di jendela, memandang ke arah Bukit Kaki lama-lama.

Jalan Kecil ke arah Bukit Kaki diperlebar, beberapa bagian mulai diaspal, tapi tetap tak pasti kapan Mak Etek pulang. Bukan hanya ibuibu dan para keluarga pihak sepupu yang kini bertanyatanya, tetapi para paman juga mulai gelisah. Dan persis saat kegelisahan itu seperti mulai tampak menghinggapi Nenek, berita besar menghantam bagai geledek: Harun terlibat kasus korupsi” (Sakai, 2012: 69).

Cerpen "Kaki yang Terhormat" memberikan kesadaran lain bagaimana arus modernisasi ini harus dihadapi. Masyarakat memiliki daya tahan (resistensi) dalam melawan berbagai efek negatif modernisasi. Kehidupan yang sudah dijalani dan memiliki sistemnya sendiri, tidak serta merta dapat diubah dengan cepat. Rencana Harun untuk mengeksploitasi sumber daya alam di kampungnya sendiri membuatnya harus berhadapan dengan bencan. Contoh seperti ini dapat diartikan bahwa masyarakat dapat menolak bahaya yang mengancam mereka akibat dari eksploitasi yang berlebihan. 


\section{Novel Andika Cahaya: Museum sebagai}

\section{Penanda Kebudayaan}

Novel ini ditulis oleh Darman Moenir, seorang pengarang yang sudah lama berkarya. Novel ini beralur maju, dimulai dari sejarah pembebasan lahan dan pembangunan sebuah museum di Kota Padang, Sumatera Barat, hingga pada bagaimana museum itu dikelola dan dikembangkan oleh para staf yang bekerja. Cerita ini dikembangkan oleh tokoh 'aku' yang menceritakan seluruh kisah, dan juga mencoba untuk memberikan detil karakter tokoh dari sudut pandang orang ketiga yang mengetahui seluruh perilaku dan dunia batin tokoh.

Cerita berpusat pada pengelolaan museum oleh Kepala Museum (Kamus) Jotambi. Jotambi merupakan kepala museum yang pertama. Dia merekrut staf museum dengan cara memasukkan keluarga, orangorang terdekat, dan orang-orang yang dikenalnya agar dia dapat mengontrol segala hal yang terjadi di museum. Perekrutan ini juga diwarnai dengan berbagai kecurangan, misalnya dengan menggunakan ijazah palsu, ujian persamaan agar mendapatkan ijazah, dan juga menyekolahkan mereka walaupun tidak sesuai dengan kompetensi mereka. Bahkan, anaknya sendiri dia sekolahkan di sebuah universitas di Bali selama 6 tahun, tetapi masih menerima gaji dan tunjangan kegiatan maupun proyek yang ada di museum. Berbagai kegiatan di museum juga penuh dengan kecurangan, penggunaan dana yang tidak transparan, honor pegawai yang tidak dibayarkan, kuitansi kosong, hingga pengadaan yang penuh kecurangan. Situasi seperti itu terus berlanjut hingga kepala museum berikutnya, yang masih dikontrol oleh Jotambi karena mereka masih menjadi lingkaran kekuasaan Jotambi dalam pelaksanaan proyek pembangunan. Segala rahasia ini masih terus dijaga karena merupakan kerja kongkalingkong yang terus dipertahankan.

Sejumlah kejanggalan birokrasi, seperti perekrutan pegawai yang penuh nepotisme dan kronisme, tindak korupsi, mental pejabat dan pegawai yang menjilat atasan, keberadaan program dan kerja museum yang tidak jelas dan bahkan menghancurkan kebudayaan, hingga konsep-konsep budaya yang bersinggungan dengan adat Minangkabau. Latar utama cerita ini adalah di Padang, khususnya di lokasi museum Sumatera Barat. Latar tempat berpusat di kompleks museum, yang berkaitan dengan latar waktu, yaitu sejak mulainya pembangunan Museum Sumatera Barat, yang dalam novel dinamakan Museum Andika Cahaya, hingga masa setelah reformasi, yang diberi tanda dengan perubahan sistem dan aturan baru pemerintahan. Perbedaan ini terlihat dari perubahan pendanaan operasional musem yang sebelumnya langsung dari pemerintah 
pusat (Jakarta), kini dikelola oleh pemerintah provinsi melalui Dinas Pariwisata dan Budaya.

Dalam novel Andika Cahaya, museum dimaknai sebagai sebuah ruang publik yang ditujukan untuk kepentingan umum, terutama bagi para kaum terpelajar (siswa, mahasiswa, peneliti) dan peminat budaya, serta masyarakat umum yang berkepentingan terhadap peninggalan dan sejarah sosial budaya. Apa yang tersimpan di museum seyogyanya adalah barang yang sudah tidak lagi ditemui atau digunakan dalam kehidupan sehari-hari, dan karena itu memiliki nilai historis dan budaya. Dengan demikian, museum memang menjadi tempat belajar dan mengenal sejarah kehidupan manusia atau masyarakat.

Berkebalikan dengan arti yang sesungguhnya, ternyata museum yang diceritakan dalam novel tersebut berisi barang-barang yang masih digunakan masyarakat, dibeli di berbagai tempat, dan tidak memiliki nilai historis, kecuali beberapa yang dikoleksi. Bagi banyak kota, terutama yang memiliki visi budaya yang jelas, museum menjadi satu bagian penting dalam memperkenalkan keberadaan wilayah atau kota tersebut. Melalui museum, para pengunjung dapat melihat dan mempelajari berbagai bendabersejarah, yang menjadi mata rantai sejarah perkembangan masyarakat.

Dalam novel ini digambarkan bagaimana museum yang seharusnya menjadi ruang publik dikelola secara tidak profesional. Berbagai program yang dikembangkan didasarkan pada kepentingan pengelolanya sehingga fungsi museum itu menjadi hilang. Mereka yang berkunjung tidak mendapatkan informasi dan pengetahuan yang memadai seperti yang diharapkan. Kontradiksi ini menjadi sesuatu yang sangat disayangkan, apalagi dilakukan oleh para pegawai pemerintah. Masyarakat tidak mendapatkan haknya terhadap pengetahuan dan informasi dari museum. Berbagai praktik korup yang digambarkan dalam novel ini hanya menjadi satu contoh kecil dari pengelolaan ruang dan fasilitas publik yang dikelola oleh pemerintah.

Museum Andika Cahaya, yang dari berbagai informasi yang disajikan di dalam novel ini, dapat dirujuk sebagai Museum Adityawarman, yang terletak di lokasi bersejarah, di mana berdiri patung yang dibuat oleh Belanda. Pada awal berdirinya, museum ini sebenarnya dapat dijadikan satu bagian penting dalam menjaga peninggalan dan perkembangan kebudayaan Sumatera Barat. Museum ini juga memiliki lahan yang sangat strategis dan cukup luas sehingga dapat menjadi ruang terbuka hijau bagi Kota Padang. Masalahnya, Taman Melati, tempat kompleks museum itu berada, lebih dikenal sebagai tempat mangkalnya para perempuan malam dan tempat terjadinya transaksi 
seksual. Hingga kini, ingatan bersama itu masih menjadi fenomena yang terjadi, apalagi di sekitar tempat itu banyak berdiri berbagai fasilitas hiburan malam. Padahal, di sekitarnya juga terdapat pusat-pusat kebudayaan dan intelektual, seperti Taman Budaya, perpustakaan wilayah, gedung Genta Budaya, masjid, kampus Fakultas Hukum Universitas Andalas, gedung PTUN, dan pasar raya. Lokasi yang sangat strategis seperti ini sebenarnya dapat membangun kondisi sosial budaya yang lebih baik, bila museum tersebut benar-benar difungsikan dan dikelola dengan baik.

Dengan pengalaman Darman Moenir sebagai staf di museum yang menjadi latar cerita novelnya, berbagai detil cerita dan peristiwa berangkat dari kejadian yang masuk akal dan merujuk pada pola birokratis yang diamati sehari-hari. Permasalahan dari novel yang ditulis Darman Moenir ini memiliki kebenaran sosiologis, dengan pola sikap para tokohnya yang diambil dari patron yang ada.

4. Novel Lonceng Cinta di Sekolah Guru: Pendidikan dan Pembentukan Karakter

Novel berjudul Lonceng Cinta di Sekolah Guru ditulis oleh Khairul Jasmi. Penulis novel ini sebelumnya lebih dikenal sebagai wartawan dari Sumatera Barat dan terakhir bekerja sebagai pimpinan redaksi Harian Singgalang. Selain sebagai wartawan,
Khairul Jasmi juga banyak menulis cerita pendek dan cerita-cerita bersambung. Belakangan ini dia tertarik untuk menulis novel. Lonceng Cinta di Sekolah Guru adalah salah satu novel terbarunya yang sudah dipublikasikan.

\section{Novel Lonceng Cinta di Sekolah}

Guru berkisah tentang seorang pemuda berhati lembut yang senang mendengar cerita-cerita dongeng atau sejarah yang dituturkan ibu atau neneknya, suka membaca, dan kemudian menjadi gemar menulis juga. Salah satu yang ditulisnya adalah surat cinta buat sahabat-sahabatnya di sekolah. Nurus -- tokoh utama yang berperan sebagai aku dalam novel ini- menyebut dirinya sebagai bagian dari generasi yang lahir di era bergolak. Perubahan-perubahan sosial akibat masuknya teknologi dan sistem kehidupan modern kekehidupan tradisional masyarakat Minangkabau menjadi sumber cerita yang mengikat seluruh rangkaian cerita dalam novel ini, di balik tema cinta remaja yang diangkat sebagai judul.

Novel ini dibuka dengan cerita tentang sekolah di mana Nurus belajar, Sekolah Pendidikan Guru (SPG), yaitu sebuah sekolah untuk calon guru sekolah dasar (SD) yang berada di Kota Padang Panjang. Sekolah ini hadir karena tuntutan akan kebutuhan guru sekolah dasar yang tinggi. Pada masanya, di era 80-an awal SPG ini merupakan sebuah sekolah yang cukup 
diminati oleh masyarakat menengah ke bawah dan keluarga petani yang bercita-cita menjadi pegawai negeri. Karena orientasinya menjadi guru SD dan mungkin juga karena stigma yang melekat dalam masyarakat bahwa guru SD adalah pekerjaan yang menuntut kesabaran tinggi dan hanya cocok dengan jiwa perempuan, maka sekolah guru seperti SPG pun muridnya kebanyakan perempuan. Karena itu pula, laki-laki yang masuk ke sekolah guru sering digelari lakilaki berpayung.

Penerimaan laki-laki Minangkabau terhadap konsep matrilinial, adaptasi laki-laki minang yang lahir dan besar dalam keluarga ibu dan harus menjalin hubungan baik dengan kerabat ayah yang disebut bako-- sebuah jalinan kekerabatan yang seringkali rumit dan penuh konflik-- dituturkan oleh penulis cerita ini dengan sederhana dan tanpa masalah. Juga tidak ada persoalan besar ketika Nurus, sebagai laki-laki Minang, harus sekolah dan bergaul dengan banyak perempuan di satu sekolah. Ini menggambarkan bahwa secara adat relasi laki-laki dan perempuan di Minangkabau buka hal yang perlu dipersoalkan. Yang menjadi persoalan adalah ketika si tokoh harus berhadapan dengan tuntutan kemodernan seperti keharusan melanjutkan pendidikan ke jenjang yang lebih tinggi sementara secara materi dia dan keluarganya tidak mampu. Ketika teknologi yang diperkenalkan kepada masyarakat lokal, seperti listrik masuk desa, kendaraan bermotor atau pupuk kimia bagi petani, bukan memberikan sumbangan kemakmuran, tetapi malah melahirkan ketergantungan. Kehidupan sosial masyarakat bawah pun menjadi gelisah. Itulah yang ditangkap oleh penulis dan digambarkan melalui penokohan Nurus, seorang pemuda Minang yang punya ambisi berbeda dari laki-laki kampung segenerasinya yang kebanyakan memilih untuk merantau, menjadi kernet bus, atau pedagang kaki lima.

Dalam novel terbarunya ini, terlihat Khairul Jasmi berusaha menampilkan catatan sejarah soal perubahan sosial masyarakat Sumatera Barat, dari masyarakat tradisional menuju masyarakat modern sepanjang rentang tahun 1955 sampai tahun 1980-an. Bagaimana masyarakat yang sebelumnya akrab dengan sekolah agama kemudian berkenalan dan menjadikan sekolah umum sebagai pilihan yang membanggakan daripada sekolah agama. Selain itu, juga diceritakan pengaruh-pengaruh teknologi, di antaranya perkenalan masyarakat dengan listrik melalui program masuk desa, perubahan pasar tradisional menjadi pasar modern, cara pandang masyarakat terhadap pimpinan pemerintahan (gubernur), serta deskripsi tentang kota kecil dan kota besar mulai dari Payakumbuh, Bukittinggi, Padang Panjang, Padang, Bengkulu, Jakarta, sampai Yogyakarta. 
Kurun waktu yang diceritakan dalam novel ini merupakan saat-saat penting dalam kehidupan sosial masyarakat Sumatera Barat, khususnya masyarakat Minangkabau. Hal tersebut terkait dengan peristiwa Pemberontakan PRRI dimana masyarakat Sumatera Barat melakukan perlawanan terhadap pemerintah pusat di Jakarta yang berakibat terhadap penumpasan gerakan PRRI oleh pemerintah Jakarta dan hal ini menjatuhkan mental dan harga diri orang Minang. Dalam Novel setebal 352 halaman ini pembahasan soal kepincangan pembangunan antara Pulau Jawa dan Sumatera dibahas dengan cukup jelas. Di samping itu, juga dibahas pengaruh desentralisasi yang dilakukan oleh pemerintah pusat terhadap wilayah-wilayah di luar Jawa berkaitan dengan kebijakan-kebijakan yang bersifat top down tanpa mengkaji kebutuhan daerah dan aspek budaya lokal.

Secara fisik, gedung sekolah yang digambarkan dalam bagian ini sangat memadai bagi perlangsungnya proses belajar mengajar dan interaksi sosial antara peserta didik dan guru. Ini adalah gambaran ideal sebuah gedung sekolah yang sangat langka untuk ukuran Kota Padang sebagai Ibu Kota Provinsi Sumatera Barat atau kota lainnya, bahkan sampai hari ini. Luasnya 5 hektar dengan dua induk bangunan, ruang belajar, dan ruangan guru, serta dua bangunan asrama putra dan putri dan tempat tinggal guru.
Sebuah gedung peninggalan Belanda. Secara sosiologis, ruang kelas yang meliputi luas, tata letak, pencahayaan dan peralatan belajar di dalamnya memberi pengaruh besar terhadap penghuni kelas juga terhadap kesuksesan program belajar mengajar. Akan tetapi, ruang kelas tentunya tidak berdiri sendiri saja. Ada unsur lain yang juga menyumbang, yaitu kompetensi guru, murid, dan kurikulum serta ideologi di balik kurikulum tersebut.

Dalam novel ini persoalan dunia pendidikan ini banyak disorot. Bagaimana ideologi di balik sistem pendidikan mempengaruhi output dari sebuah sistem. SPG, sekolah guru yang didirikan untuk tujuan praktis memenuhi kebutuhan guru sekolah dasar. Karena tujuan praktis seperti ini dan karena masa depan yang jelas: Sebagai guru SD dengan penghasilan kecil, maka keberadaan sekolah ini dipandang kurang bergengsi. Dan yang bersekolah di sekolah tersebut biasanya hanyalah anak petani atau mereka yang datang dari keluarga dengan strata sosial menengah ke bawah. Dan juga perempuan. Banyaknya perempuan di sekolah guru jelas ada kaitannya dengan distingsi sosial dalam masyarakat yang memandang pekerjaan guru terutama guru SD identik dengan perempuan.

Pada bagian "Asrama Bidadari”, pengarang mencoba menggambarkan bagaimana pendisiplinan dan pendidikan berasrama membentuk dan memengaruhi 
kepribadian seorang pelajar muda di Sekolah Pendidikan Guru (SPG) yang menerapkan kurikulum nasional/sekuler dibandingkan dengan pendidikan berasrama model sekolah agama seperti Diniyah Putri yang juga ada di kota yang sama. Digambarkan bagaimana penghargaan orang (masyarakat) terhadap anak-anak sekolah putri Diniyah dan bagaimana perilaku mereka menjaga sikap dalam masyarakat yang berbanding terbalik dengan perilaku anak-anak asrama SPG yang diam-diam suka berpacaran di luar asrama, suka merokok dan menonton bioskop.

Pada bagian ini juga disinggung tentang rel kereta api yang merupakan jalur transportasi utama antarkota di Sumatera Tengah yang sejak tahun 1970 sudah tidak berfungsi lagi. Soal stasiun kereta yang telah berubah fungsi menjadi deretan pertokoan menggantikan los tua tempat petani kecil menukarkan hasil kebun mereka dengan pedagang perantara yang mencari dagangan untuk dibawa ke kota yang lebih ramai seperti Padang, Bukittinggi atau Pekanbaru.

"Tapi ketika aku sekolah di Padang Panjang, kota itu sudah berubah. Nenek berkaki ayam, yang tak bisa naik mobil, yang ke pasar membawa sesisir dua sisir pisang, tiga atau empat biji kol, sudah tidak ada lagi. Mereka disisihkan dari kota yang mereka bangun. Pemerintah telah merampas sejarah kecil dari dada si nenek. Kini Ruko bermunculan, yang hanya bisa dimiliki orang berduit" (Sakai, 2012: 29-30).

Persepsi masyarakat ini mulai terbentuk karena proses stereotyping atas berbagai gejala dan fenomena, misalnya saja dalam pandangan masyarakat bahwa profesi guru, dan juga murid-murid sekolah guru, merupakan dominasi perempuan. Karena itu, ketika ada murid atau guru yang berjenis kelamin laki-laki, mereka akan diidentifikasikan sebagai laki-laki berpayung. Pandangan ini pada awalnya memang bernada negatif, akan tetapi pada masa sekarang, terutama di kota-kota, profesi tidak memandang jenis kelamin.

\section{Sastra Urban dan Sumatera Barat:} Sebuah Gambaran dalam Karya Sastra

Gambaran mengenai wilayah, terutama perkotaan, menjadi latar dan sumber permasalahan yang banyak diolah dalam karya sastra. Pertama-tama, wilayah yang terdekat dengan diri pengarang menjadi pilihan. Hal ini disebabkan oleh permasalahan yang terjadi, penciptaan karakter, latar belakang budaya, visualisasi dan deskripsi di dalam karya sastra, bahasa, dan penyelesaian konflik dapat dikuasai dengan baik oleh pengarang. Para pengarang Sumatera Barat, seperti telah dibahas dalam artikel ini, memperlihatkan persoalan besar yang terjadi 
dalam masyarakat perkotaan. Persoalan ini menjadi sumber penciptaan yang kemudian diolah dalam karya sastra. Akan tetapi, sejauh mana kota dengan segala persoalannya, dan juga sumber penciptaan lainnya, disampaikan dalam karya sastra, itu merupakan sebuah pertanyaan penting yang muncul.

Dua novel dan dua kumpulan cerpen yang dibahas dalam artikel ini, misalnya, mengambil sisi-sisi tertentu dari kehidupan, dalam hubungannya dengan kota dan juga wilayah lain, desa atau kampung, sebagai sebuah pembanding. Novel Andika Cahaya menyajikan aktivitas di sebuah kantor pemerintah sebagai sebuah ilustrasi tentang berbagai kebobrokan birokrasi, yang penuh dengan kepentingan pribadi atau kroni, dengan menggerogoti uang rakyat dengan berbagai modus operandi. Contoh seperti ini nyaris dapat kita temui setiap saat, baik melalui media informasi atau pengalaman sehari-hari ketika berurusan dengan aparat pemerintahan. Akan tetapi, novel ini memberikan sebuah gambaran yang cukup lengkap dengan berbagai sudut pandang bagaimana sebuah kantor pemerintah beroperasi. Namun demikian, apakah novel ini mampu menghadirkan representasi kehidupan kota, misalnya dalam aktivitas kantor, profesi penyedia jasa layanan umum, dalam sebuah gambaran yang memadai? Hal yang sama juga dapat disematkan pada novel Lonceng Cinta di Sekolah Guru. Novel ini tidak saja memusatkan perhatian pada kehidupan di sebuah lembaga pendidikan, tetapi juga merangkum gambaran sosial dan lingkungan masyarakatnya.

Dari pembacaan karya yang dibahas, persoalan pendidikan, kemiskinan, hubungan antar individu, gaya hidup modern, hingga kebudayaan dan pengelolaannya menjadi persoalan yang diungkap dalam karya sastra. Peringatan yang diberikan oleh para pengarang, dengan menghadirkan berbagai persoalan dalam masyarakat yang dibahas dalam karya sastra mereka, hendaklah diperhatikan oleh pembaca. Para pengarang telah menemukan berbagai persoalan kemanusiaan dalam masyarakat urban, khususnya yang dekat dengan kehidupan mereka, dan menghadirkannya dalam karya sastra. Dengan demikian, berdasarkan karya sastra yang dibahas dalam artikel ini, kemajuan yang telah diperoleh dalam modernitas, terutama dalam masyarakat urban, diikuti oleh berbagai perubahan dan masalah yang harus disadari oleh masyarakat. Sifat dinamis dan kompleks yang tergambar dalam masyarakat perkotaan, dibandingkan dengan masyarakat pedesaan atau rural, memberikan ruang yang lebar bagi sastrawan untuk ikut serta mengingatkan dalam karyakarya mereka.

Dalam pandangan para pengarang yang dikemukakan dalam karya sastra yang 
telah dibahas di atas, kota digambarkan memiliki kompleksitas persoalan. Sebagai sebuah daerah urban, Kota Padang juga tidak terhindar dari pengaruh buruk akibat arus urbanisasi. Melalui karya sastra ini pembaca diingatkan dan sekaligus diminta untuk mempersiapkan diri dalam menghadapi segala pengaruh yang ada. Meskipun demikian, kesadaran Padang sebagai sebuah wilayah urban atau perkotaan, di mana orang dari berbagai penjuru datang, tinggal, menetap, melakukan aktivitas, sedikit banyak dipengaruhi dan memengaruhi identitas budaya kota ini. Tarik-menarik identitas budaya ini dapat berwujud dalam berbagai bentuk, disebabkan interaksi manusia yang heterogen, atau juga karena ekspansi dan masuknya pengaruh budaya luar lewat berbagai media. Persoalan inilah yang berjalan hingga kini, karena daya resistensi, terutama dengan alasan sosial budaya, berbagai tema dan isu masih menarik untuk dibahas dan ditelusuri lebih jauh. Kota Padang di satu sisi juga menyisakan persoalan identitas budaya, sebagaimana terlihat dalam sebagian besar karya sastra yang dihasilkan oleh para pengarang. Bahkan, seperti ditunjukkan oleh sejumlah cerpen karya Gus tf Sakai, persoalan urban ini juga telah merangkak masuk ke kotakota kecil dan kampung-kampung. Sisi yang banyak dilihat dari masuknya budaya urban ke daerah-daerah ini adalah sisi negatifnya, seakan memberikan peringatan akan bahaya dan dampak buruk yang diakibatkan oleh modernitas terhadap tatatan masyarakat.

Bagi pengarang seperti Darman Moenir, sebagaimana terlihat dalam novelnya yang telah dibahas, kehadiran ruang publik seperti museum patut untuk dipertahankan dan dikelola dengan baik. Karena alasan peruntukan dan keterbatasan lahan dan fasilitas umum, seperti yang terlihat hampir di semua karya sastra yang dibahas, masyarakat yang tinggal di kota terlihat seperti terlepas dan terbatas dari kehidupan alaminya. Hal ini berpengaruh pada sikap mental, psikologi, dan hubungan sosial dan ekologi, yang menciptakan kekhasan dalam rutinitas dan problatika hidup mereka.

Dari karya sastra yang telah dibicarakan, terdapat proses internalisasi dalam diri pengarang yang kemudian terolah dalam karya mereka. Selain pada dinamika manusia yang bermukim di kota, yang membangun karakter dan sikap, berbagai lanskap dan fasilitas yang menjadi ciri perkembangan kota juga diabadikan dalam karya sastra. Pada cerpen Gus tf Sakai, kehadiran pabrik menjadi penciri masalah bagi kota yang sedang berkembang. Demikian juga dengan pembangunan museum dalam novel Darman Moenir pada satu sisi menjadi ruang publik, tetapi pada sisi yang lain menjadi simbol bagi praktik pemerintahan yang cenderung korup. Sementara itu dalam 
novel karya Khairul Jasmi, sekolah menjadi sebuah fasilitas bagi terbentuknya masa depan masyarakat. Pembahasan ini difokuskan pada penanda dinamika kota yang terdapat dalam karya sastra yang dibahas, yaitu kompleks perumahan dan pabrik, museum, dan sekolah. Penanda kehidupan kota ini tidak hanya dijelaskan melalui bangunan atau fasilitas, akan tetapi juga harus disertai dengan bagaimana manusia yang hidup di kota menjadi aktor utama dinamika kota. Kesadaran para pengarang terhadap kehidupan urban ini dapat dijelaskan melalui pengolahan arus urbanisasi dalam karyakarya sastra.

\section{Simpulan}

Artikel ini membahas empat karya sastra yang ditulis oleh para pengarang dari Sumatera Barat. Keempat karya sastra yang dibicarakan menghadirkan persoalan masyarakat urban dengan segala karakteristik yang dimilikinya. Karya sastra yang dibahas dalam artikel ini hanya sebagian saja dari banyak karya sastra yang mengangkat tema sejenis. Persoalan urban, seperti dampak modernisme, gaya hidup, pekerjaan, norma, produk kebudayaan populer, hingga kemajuan teknologi, telah membawa perubahan penting dalam masyarakat. Selain sisi baik dari perubahan itu, terdapat banyak sisi kelam dan akibat buruk yang ditimbulkan.
Kehadiran karya sastra yang mengangkat isu dan tema urban merupakan alarm, yang dapat dijadikan bahan pertimbangan untuk memikir ulang situasi yang telah dan sedang terjadi. Pembaca dapat membandingkan perubahan-perubahan yang terjadi dalam masyarakat di kotakota besar dengan kota-kota menengah dan kecil. Karya sastra yang dibicarakan dalam tulisan ini sebagian besar mengungkap fenomena urbanisme dalam kota menengah ini. Pengarang-pengarang yang menulis karya-karya ini juga tinggal dan menjadi bagian dari kota menengah yang sedang bergerak menuju perkembangan berikutnya. Dengan demikian, persoalan yang dihadirkan tidak asing bagi pembaca. Karena itu, kita, pembaca, dapat mengaitkan persoalan yang ada dengan karya sastra tersebut, dan mencari benang merah, lalu menumbuhkan kesadaran terhadap situasi yang ada. 


\section{Daftar Pustaka}

Bain, Lauren. 2002. "Indonesia dari Sebuah Hotel” dalam Kalam edisi khusus Ihwal Kota, 2002.

Budiman, Manneke. 2006. "Viewing the Nation from the City in Contemporary Indonesian's Women Urban Writing", in Arts, popular cultures and social change in the new Indonesia; Seminar Proceeding, ed. Michael Leaf, Centre for Southeast Asia Research. Canada: Univerity of British Colombia.

Fuller, Andy. 2010. "Jakarta Flanerie: Selected Writings of Seno Gumira Ajidarma”. PhD Thesis. Australia: Tasmania University.

Fuller, Andy. 2010. Sastra dan Politik: Membaca Karya-karya Seno Gumira Ajidarma, Yogyakarta: Insist Press.

Hendrik, Makmur, 2012. "Lonceng Cinta Khairul Jasmi” Harian Haluan 19 April 2012. Padang: Harian Haluan.

Jasmi, Khairul. 2012. Lonceng Cinta di Sekolah Guru. Jakarta: Gramedia Pustaka Utama.

KW, Yusrizal. 2004. Kembali ke Pangkal Jalan. Jakarta: Penerbit Buku Kompas.

Moenir, Darman. 2012. Andika Cahaya. Yogyakarta: Akar.

Naaman, Mara. 2011. Urban Space in Contemporary Egyptian Literature: Portraits of Cairo. New York: Palgrave Macmillan.

Rotella, Carlo. 1998. October Cities: The Redevelopment of Urban Literature. California: University of California Press.

Sakai, Gus tf. 2012. Kaki yang Terhormat. Jakarta: Gramedia Pustaka utama.

Sutan, Fadlillah Malin, 2012. "Biografi Museum Kekuasaan, Membaca Novel Andika Cahaya Karya Darman Moenir" Harian Haluan 8 Juli 2012. Padang: Harian Haluan. 